\title{
Biochemical analysis of some fruit peels and comparison of Lactic acid production by authochthonous Lactic acid bacteria using fruit peels
}

Arekemase M.O., Adetitun D.O.* \& Ahmed M.I.

Department of Microbiology, Faculty of Life Sciences, University of Ilorin, P.M.B. 1515 Ilorin, Kwara State. Nigeria

\begin{abstract}
Waste to wealth is a common trend in the world today. This work reports the utilization of waste fruit peels for production of lactic acid using authochthonouslactic acid bacteria. Peels of mango, orange and banana were prepared in powdered form, pretreated with $\mathrm{HCl}$ and added as carbon source for lactic acid production. The proximate analyses of the substrates were done. The organisms used for fermentation were isolated from spoilt banana and identified using biochemical and molecular tools. These organisms were grown using different growth factors over a period of eight days with initial $\mathrm{pH}$ of 6.0. Growth factors were then varied in order to optimize the yield of lactic acid. Percentage production of lactic acid was determined every 24 hours. The optimized conditions were then combined for further comparison. Isolated Lactobacillus plantarumand Lactobacillus caseiwere used for the production of lactic acid. The carbohydrate content of mango, banana and orange peels $(62.48 \%, 55.34 \%$ and $57.06 \%$ respectively) showed that it was sufficient for use as a carbon source. The highest yield of lactic acid $(27.10 \%)$ was at $\mathrm{pH} 6.0$ with $2 \mathrm{~g}$ of substrate and $1 \mathrm{ml}$ inoculum at day six by Lactobacillus caseiwhile the highest yield by Lactobacillus plantarum $(23.85 \%)$ was at $\mathrm{pH} 6.0$, with $4 \mathrm{~g}$ of substrate and $2 \mathrm{ml}$ inoculum at day six. The highest production of lactic acid was derived when mango peels were used. The results of this study showed that lactic acid can be produced using mango, orange and banana peels.
\end{abstract}

Received: 21 May 2019

Accepted: 24 Oct 2019

\section{Key words:}

lactic acid;

food waste;

Lactobacillus casei;

Lactobacillus plantarum; optimization

*Corresponding author: adetitun.do@unilorin.edu.ng

iD https://orcid.org/0000-00033814-8783

Tel: +238036910988

\section{Introduction}

Fruit based industry produces a large volume of solid and liquid waste. These pose increasing disposal and pollution problems (high BOD or COD) and represents loss of valuable biomass and nutrients (Mridul\&Preethi, 2014).Disposal of wastes from fruit-canning industries has been a problem due to high transportation costs and limited availability of landfills, as these byproducts carry no commercial value, they are often discharged in places they ought not to be disposed (Pradeep et al., 2014). This particularly occurs where there is a lack of legislation and their enforcement on waste disposal (Omojasolaet al., 2009). These wastes directly affect environmental agencies and municipalities because food waste is a primary source of methane gas in landfills (Gunders, 2012).

Recycling fruit-waste to develop new products has received much attention lately. Organic waste treatment processes (Purkayastha, 2012) and anaerobic digestion processes (Shin et al., 2010; Dai et al., 2013; Bernstadet al., 2013) are two promising technologies used in this regard. Presently, the main use of such domestic food waste is the production of valuable compounds by the controlled break down of the waste by microorganisms (Rounsefellet al., 2013).

Lactic acid has gained importance for its application in food, feed, chemical, pharmaceutical and beverage industries (Ray \& Swain, 2011). Most important application of lactic acid is its use 
for the manufacture of biodegradable and biocompatible polylactate polymers (Khalaf, 2001). Microbial sources including many bacteria such as

Carnobacterium, Enterococcus, Lactobacillus, Lactococcus, Leuconostoc, Streptococcus, Clostridium and Weissellahave been reported to produce lactic acid (Bogaert\&Coscach, 2000).

Due to the importance of this organic acid, there are ongoing research efforts related to its production (Hofvendahl\& Hahn- Hägerdal, 2000). Variations in temperature, $\mathrm{pH}$ and nitrogen sources affect lactic acid production (Pavezziet al., 2008; Jörissenet al., 2015).

The aim of this study was to evaluate the effect of physical, chemical and nutritional parameters on the production of lactic acid with the aid of two lactic acid bacteria.

\section{Materials and Methods}

Banana, orange and mango fruits were procured from a local market near Ilorin. The fruits were authenticated at the herbarium unit of the Department of Plant Biology, University of Ilorin, with voucher specimen numbers UILH/001/996, UILH/002/1080 and UILH/003/1249 respectively. These fruits were washed with clean water to remove dirt and then peeled. The peels were air dried at $50{ }^{\circ} \mathrm{C}$ in an oven to a constant weight. The peels were pounded with mortar and pestle and blended to derive fine particle sizes. The powdered product was stored in a cool, dry place to avoid uptake of moisture and then used as fermentation feedstock according to the protocol of Nandini et al. (2014).

\section{Determination of Ash Content and crude protein}

Two gram each of each sample was weighed into small dry crucibles of known weight. Each sample was charred in the crucible on low flame. The charred materials were ashed in a furnace at red heat for 3 hours. Thereafter, each material was cooled, weighed and kept in a desiccator (Cullison, 1982; AOAC, 2000). The nitrogen concentration of the by-product sample was determined by employing the micro-Kjeldahl method. (AOAC, 2000).

\section{Determination of Crude Fibre}

A known quantity (3.5g) of the defatted sample used for the lipid assay was transferred into a 500 $\mathrm{ml}$ conical flask $\left(\mathrm{W}_{1}\right), 200 \mathrm{ml}$ of boiling $\mathrm{H}_{2} \mathrm{SO}_{4}$ $(1.25 \%)$ was added, boiled within one minute and then allowed to boil gently for 30 minutes (Ibitoye,
2005). It was then filtered through filter paper using a Büchner funnel and rinsed well with hot distilled water. The residue obtained after filtration was dispensed into the flask with the aid of a spatula. To the same conical flask, $1.25 \% \mathrm{NaOH}$ $(200 \mathrm{ml})$ was added and boiled for 45 minutes and filtered. This procedure was repeated again, followed by addition of $200 \mathrm{ml}$ of $10 \% \mathrm{HCl}$. After filtration, the resulting filtrate was diluted with 200 $\mathrm{ml}$ of water and filtered. This was repeated twice, allowed to dry and it was weighed. The \% crude fibre content was calculated as follows:

$$
\text { Percentage crude fibre }=W 2-\frac{W 3}{W 1} * \frac{100}{1}
$$

\section{Determination of Fat, Moisture and Dry Matter Content}

This was determined using the Soxhlet method of extraction according to standard protocols (AOAC, 2000). The moisture content was determined by the loss in weight that occurred when the samples were dried to a constant weight in a regulated oven (Gallenkamp) according to the method used by Cullison (1982) and AOAC (2000).

\section{Carbohydrate content (Nitrogen Free Extract)}

The Nitrogen Free Extract (N.F.E.) referred to as soluble carbohydrate was obtained as a fraction part (in percentage) of the sample after subtracting other components such as the ash content, crude lipid, crude protein and crude fibre.

$\%$ carbohydrate $=100-(\%$ moisture $+\%$ crude lipid $+\%$ crude fibre $+\%$ ash content $+\%$ crude protein).

\section{Isolation and Identification of Lactic Acid Bacteria (LAB)}

The lactic acid bacteria (LAB) used in the study were isolated from spoilt banana fruit using the spread plate method. Man Rogosa Sharpe (MRS) agar $\left(\right.$ Oxoid $\left.^{\mathrm{TM}}\right)$ was used. The plates were incubated at $35 \pm 2{ }^{\circ} \mathrm{C}$ for 24 hours. The pure axenic cultures were stored at $4{ }^{\circ} \mathrm{C}$. Identification of bacterial isolates was carried out by biochemical reactions as described in Bergey's Manual of Determinative Bacteriology (Holt, 1994). The bacterial isolates were identified based on morphological and biochemical characteristics. Identification was further confirmed by molecular tools using their 16S rRNA with 16SF (5'AGAGTTTGATCCTGGCTCAG3') and (5'TACCTTGTTACGACTT3') primers to get an amplicon size of 1500 bp., gel electrophoresis, sequencing and BLASTn on NCBI database based on percentage similarities with those on the database.

\section{Acid hydrolysis}


The modified method of Puimputet al., (2008) was used for substrate hydrolysate preparation. Exactly $50 \mathrm{ml}$ of $0.5 \mathrm{HCl}$ was added to $2 \mathrm{~g}$ each of the wastes and boiled at $80{ }^{\circ} \mathrm{C}$ for $30 \mathrm{~min}$. The hydrolysate was recovered by filtration with Whattman filter paper no 1.

\section{Inoculum preparation}

The pure isolates were grown on Man Rogosa Sharpe (MRS) agar. They were sub-cultured in 50 $\mathrm{ml}$ liquid synthetic MRS medium instead of distilled water. The above medium was placed on a rotary incubator shaker at $35{ }^{\circ} \mathrm{C}$ and $120 \mathrm{rpm}$ for 3 days as described by Mahanteshet al. (2010).

\section{Media and fermentation conditions}

The fermentation medium was compounded as described by Quiroga et al. (2014). Measured inoculum was dispensed in an oven sterilized test tube after the third day of incubation. The supernatant was discarded after centrifugation (150 rpm for 10mins), $10 \mathrm{ml}$ of sterile water was added to the pellet and mixed. Exactly $1 \mathrm{ml}$ of the mixture was introduced into $50 \mathrm{ml}$ of each of the sterile fermenting medium. The fermentation broth was incubated at $35^{\circ} \mathrm{C}$ at $150 \mathrm{rpm}$ for 8 days. Lactic acid production was monitored every $24 \mathrm{hrs}$. The final $\mathrm{pH}$ was adjusted using $2 \mathrm{M} \mathrm{NaOH}$ or $1 \mathrm{M} \mathrm{HCl}$.

Determination of optimal conditions for lactic acid production

The optimization experiments were carried out to find out the effects of fermentation time, $\mathrm{pH}$, inoculum size, quantity of substrate and nitrogen on the production of lactic acid. Fifty milliliters of the fermenting media in $250 \mathrm{ml}$ Erlenmeyer flasks at initial $\mathrm{pH} 6.0$ was inoculated by the test organisms, and incubated at $35^{\circ} \mathrm{C}$ on a rotary shaker $(150 \mathrm{rpm})$ for 8 days. Samples were withdrawn at 24-hour intervals for the estimation of lactic acid content. The initial $\mathrm{pH}$ of the fermentation medium was adjusted with $2 \mathrm{M} \mathrm{NaOH}$ or $1 \mathrm{M} \mathrm{HCl}$ to values ranging from 5.0-6.5. Thereafter the flasks were inoculated and incubated at $35^{\circ} \mathrm{C}$ for 8 days on a rotary shaker $(150 \mathrm{rpm})$. Fifty milliliters of fermentation medium (initial $\mathrm{pH} 6.0$ ) in $250 \mathrm{ml}$ Erlenmeyer flasks were inoculated with 3-day old culture, with different inoculum sizes $(0.5,1.0,1.5$ and $2.0 \%$ ) and incubated at $35{ }^{\circ} \mathrm{C}$ for 8 days with agitation at $150 \mathrm{rpm}$. The quantity of substrate added to $10 \mathrm{ml}$ mineral salt medium was varied and ranged from $1 \mathrm{~g}$ to $4 \mathrm{~g}$.

\section{Optimization experiments}

Optimization experiments were carried out by taking the $\mathrm{pH}$ values that produced the highest yield of lactic acid, the inoculum size that gave the highest yield and the substrate quantity that gave the highest yield. All these parameters were then combined in a single experiment to determine the optimum conditions for lactic acid production.

\section{Quantification of the lactic acid produced}

The production of lactic acid was detected by estimating the titratable acidity of the fermentation medium against $1 \mathrm{~N} \mathrm{NaOH}$. Two milliliters of culture broth was taken from the fermented broth in a flask and $8 \mathrm{ml}$ of distilled water was added to make up $10 \mathrm{ml}$ and then boiled for $1 \mathrm{~min}$ to remove air. A drop of phenolphthalein indicator was added. Thereafter, $1 \mathrm{~N} \mathrm{NaOH}$ solution was added with continuous shaking till the formation of pink colour was observed. The quantity of $\mathrm{NaOH}$ utilized in the titration was measured (Quiroga et al., 2014). The amount of Lactic acid was determined by using the formula.

$\%$ of lactic acid $=\frac{\text { ml of } \mathrm{NaOH} * \text { Conc.of } \mathrm{NaOH} * 0.090 * 100}{\text { Weight of sample }}$

0.090 is milliequivalent weight of lactic acid

\section{Lactic acid recovery and purification processes}

Various recovery and purification schemes used in industry were reported by Vickroy (1985) and Benninga (1990). The first step in the recovery processes was to raise the broth's temperature to 80-100 ${ }^{\circ} \mathrm{C}$ and increasing the $\mathrm{pH}$ to $10-11$ [using $\left.\mathrm{Ca}(\mathrm{OH})_{2}\right]$ to inactivate the microorganisms, coagulate the protein, solubilize calcium lactate and degrade some of the residual sugars. The cells and coagulated protein were removed by filtration to produce a crude lactic acid extract. This crude extract was processed further by the following methods.

\section{Filtration, carbon treatment and evaporation}

Activated carbon was mixed with the crude extract to remove the coloured components. The spent carbon was then filtered out, and the filtrate was sent to the evaporator where excess water was evaporated under mild vacuum at moderate temperature $\left(0.57 \mathrm{~atm}\right.$ and $\left.70{ }^{\circ} \mathrm{C}\right)$ to $37 \%$ calcium lactate concentration. This preparation was then acidified with $63 \%$ sulfuric acid to precipitate calcium sulfate, which was filtered out. The lactic acid was bleached a second time and then evaporated to 52 or $82 \%$ concentration. Food-grade lactic acid was treated with sodium sulfide to remove heavy metals and was bleached again before packaging. This process produced only food-grade and technical-grade lactic acid. It was also energy-intensive because the concentration process relied heavily on evaporation of excess water. Furthermore, large amounts of salt $\left(\mathrm{CaSO}_{4}\right)$ were also produced, which created a waste disposal problem. 


\section{Statistical Analysis}

The data were statistically analyzed as a randomized complete block design. The means and standard deviation were compared by a one-way analysis of variance (ANOVA) (SPSS 15.0).

\section{Results}

\section{Isolation and Identification of test organisms}

The detected bacteria were Lactobacillus plantarumstrainNM71-7, Lactobacillus caseistrain AT4-518F, Lactobacillus fermentum strain CAU2928 and Lactobacillus plantarum strain B15.

DNA sequence of Lactobacillus caseistrain NM717

CCGGAGTAGCGGGTTTTCCGAGACTCTATGGGCGTAA GCGAGCGCAGGCGGTTTTTTAAGTCTGATGTGAAAGCC CTCGGCTTAACCGAGGAAGCGCATCGGAAACTGGGAA ACTTGAGTGCAGAAGAGGACAGTGGAACTCCATGTGT AGCGGTGAAATGCGTAGATATATGGAAGAACACCAGT GGCGAAGGCGGCTGTCTGGTCTGTAACTGACGCTGAG GCTCGAAAGCATGGGTAGCGAACAGGATTAGATACCC TGGTAGTCCATGCCGTAAACGATGAATGCTAGGTGTTG GAGGGTTTCCGCCCTTCAGTGCCGCAGCTAACGCATTA AGCATTCCGCCTGGGGAGTACGACCGCAAGGTTGAAA CTCAAAGGAATTGACGGGGGCCCGCACAAGCGGTGGA GCATGTGGTTTAATTCGAAGCAACGCGAAGAACCTTA CCAGGTCTTGACATCTTTTGATCACCTGAGAGATCAGG TTTCCCCTTCGGGGGCAAAATGACAGGTGGTGCATGGT TGTCGTCAGCTCGTGTCGTGAGATGTTGGGTTAAGTCC CGCAACGAGCGCAACCCTTATGACTAGTTGCCAGCATT TAGTTGGGCACTCTAGTAAGACTGCCGGTGACAAACC GGATGAAGGTGGGGATGACGTCAAATCATCATGCCCC TTATGACCTGGGCTACACACGTGCTACAATGTATGGTA CACCGAGTTGCGAGACCGCGAGGTCAAGCTAATCTCA TAAGGCAGTTCTCAGTTCGGACTGTAAGCAGCAACCTC GGCCTACCCGTAGTCGGAATCAGCTAGTAGATCGACG ATCGACCACCGCCCGCGGTGAATACGTTTCCCGGGCTC TTAAAAGAACC

\section{DNA sequence of Lactobacillus plantarumstrain AT4-518F}

TGTTGGACTGATGGGGTACGTGACGGGTCTATTGGGCG TAAGCGAGCGCAGGCGGTTTTTTAAGTCTGATGTGAAA GCCTTCGGCTCAACCGAAGAAGTGCATCGGAAACTGG GAAACTTGAGTGCAGAAGAGGACAGTGGAACTCCATG TGTAGCGGTGAAATGCGTAGATATATGGAAGAACACC AGTGGCGAAGGCGGCTGTCTGGTCTGTAACTGACGCT GAGGCTCGAAAGTATGGGTAGCAAACAGGATTAGATA CCCTGGTAGTCCATACCGTAAACGATGAATGCTAAGTG TTGGAGGGTTTCCGCCCTTCAGTGCTGCAGCTAACGCA TTAAGCATTCCGCCTGGGGAGTACGGCCGCAAGGCTG AAACTCAAAGGAATTGACGGGGGCCCGCACAAGCGGT GGAGCATGTGGTTTAATTCGAAGCTACGCGAAGAACC TTACCAGGTCTTGACATACTATGCAAATCTAAGAGATT AGACGTTCCCTTCGGGGACATGGATACAGGTGGTGCA TGGTTGTCGTCAGCTCGTGTCGTGAGATGTTGGGTTAA
GTCCCGCAACGAGCGCAACCCTTATTATCAGTTGCCAG CATTAAGTTGGGCACTCTGGTGAGACTGCCGGTGACA AACCGGAGGAAGGTGGGGATGACGTCAAATCATCATG CCCCTTATGACCTGGCTACACACGTGCTACAATGGATG GTACAACGAGTTGCGAACTCGCGAGAGTAAGCTAATC TCTTAAAGCAATTCTCAGTTCGGATTGTAGCTGCAACT CGCCTACATGAAGTCCGCATCACTAGTAATCGACGATC GAGCATGCCCGCGGTGAATAACGTTCTCCCCGGGGCTC TTAAAAAAAGGG

\section{DNA sequence of Lactobacillus fermentumstrain CAU2928}

CGCAACAGAAGGCCCCAAGGGTTTCTCTTGGGCGTAA GAGAGTGCAGGCGGTTTTCTAAGTCTGATGTGAAAGC CTTCGGCTTAACCGGAGAAGTGCATCGGAAACTGGAT AACTTGAGTGCAGAAGAGGGTAGTGGAACTCCATGTG TAGCGGTGGAATGCGTAGATATATGGAAGAACACCAG TGGCGAAGGCGGCTACCTGGTCTGCAACTGACGCTGA GACTCGAAAGCATGGGTAGCGAACAGGATTAGATACC CTGGTAGTCCATGCCGTAAACGATGAGTGCTAGGTGTT GGAGGGTTTCCGCCCTTCAGTGCCGGAGCTAACGCATT AAGCACTCCGCCTGGGGAGTACGACCGCAAGGTTGAA ACTCAAAGGAATTGACGGGGGCCCGCACAAGCGGTGG AGCATGTGGTTTAATTCGAAGCTACGCGAAGAACCTTA CCAGGTCTTGACATCTTGCGCCAACCCTAGAGATAGGG CGTTTCCTTCGGGAACGCAATGACAGGTGGTGCATGGT CGTCGTCAGCTCGTGTCGTGAGATGTTGGGTTAAGTCC CGCAACGAGCGCAACCCTTGTTACTAGTTGCCAGCATT AAGTTGGGCACTCTAGTAAGACTGCCGGTGACAAACC GGAGGAAGGTGGGGACGACGTCAGATCATCATGCCCC CTTATGACCTGGGCTACACACGTGCTACAAATGGGAC GGTACAACGAGTCGCGAACTCGCGAGGGGCAAGCAAA TCCTCTTAAAAACCGTTCTCAGTTCGGACTGCAGGCTG GCAACTCGCCTGCTCGAAGTCGGAATCGCTAGTATCCG CGGATCAGCATGCCCGCGGTGAAATACGTTTCCCCGG GTCTAAAAAAAA

\section{DNA sequence of Lactobacillus plantarumstrain B15}

CCCATTCGAAGGGGCCGATTTGGGTCTCGATGGGCAAT AAGCGAGCGCAGGCGGTTTTTTAAGTCTGATGTG AAAGCCTTCGGCTCAACCGAAGAAGTGCAT CGGAAACTGGGAAACTTGAGTGCAGAAGA GGACAGTGGAACTCCATGTGTAGCGGTGAA ATGCGTAGATATATGGAAGAACACCAGTGG CGAAGGCGGCTGTCTGGTCTGTAACTGACG CTGAGGCTCGAAAGTATGGGTAGCAAACA GGATTAGATACCCTGGTAGTCCATACCGTA AACGATGAATGCTAAGTGTTGGAGGGTTTC CGCCCTTCAGTGCTGCAGCTAACGCATTAA GCATTCCGCCTGGGGAGTACGGCCGCAAGG CTGAAACTCAAAGGAATTGACGGGGGCCC GCACAAGCGGTGGAGCATGTGGTTTAATTC GAAGCTACGCGAAGAACCTTACCAGGTCTT GACATACTATGCAAATCTAAGAGATTAGAC GTTCCCTTCGGGGACATGGATACAGGTGGT GCATGGTTGTCGTCAGCTCGTGTCGTGAGA TGTTGGGTTAAGTCCCGCAACGAGCGCAAC 
CCTTATTATCAGTTGCCAGCATTAAGTTGG GCACTCTGGTGAGACTGCCGGTGACAAACC GGAGGAAGGTGGGGATGACGTCAAATCAT CATGCCCCTTATGACCTGGGCTACACACGT GCTACAATGGATGGTACAACGAGTTGCGAA CTCGCGAGAGTAAGCTAATCTCTTAAAGCA TTCTCAGTTCGGATTGTAGGCTGCAACTCG CCTACATGAAGTCGAATCGCTAGTAATCGC GATCAGCATGCGCGGTGATACGTTTCCCGG TCCTAAAAAGAA

\section{Properties of substrates used}

The proximate composition of the substrates used is presented in Table 2. The production of lactic acid gave a maximum yield of $10.53 \%, 6.75 \%$ and
$5.40 \%$ on day 6 with mango, banana and orange peels respectively using $L$. plantarum. This is presented in Table 3 , while $L$. casei gave a maximum yield of $12.03 \%, 8.10 \%$ and $7.20 \%$ on day 6 with mango, banana and orange peels respectively as presented in Table 4 .

The effects of varying fermentation time on the production of lactic acid for $L$. plantarum and $L$. caseiare shown in Table 3 and 4 respectively. The production of lactic acid by the two test organisms using mango, banana and orange peels increased progressively up to day 6 of fermentation, and then dropped sharply on day 7.

\begin{tabular}{lcccc} 
Table 1. Colonial, Morphological and Biochemical Characteristics of Bacterial Isolates & \\
\hline Isolate & B1 & B2 & B3 & B4 \\
\hline Colonial characteristics & $\begin{array}{c}\text { Circular, convex, entire, } \\
\text { cream, smooth, opaque }\end{array}$ & $\begin{array}{c}\text { Irregular, raised, undulate, } \\
\text { cream, moist, opaque }\end{array}$ & $\begin{array}{l}\text { Circular, raised, entire, } \\
\text { cream, smooth, opaque }\end{array}$ & $\begin{array}{l}\text { Circular, convex, entire, } \\
\text { cream, smooth, opaque }\end{array}$
\end{tabular}

\begin{tabular}{|c|c|c|c|c|}
\hline $\begin{array}{l}\text { Morphological } \\
\text { characteristics }\end{array}$ & Rods in cluster & Rods in chain & Rods in chain & Rods in cluster \\
\hline Gram reaction & + & + & + & + \\
\hline Spore staining & - & - & - & - \\
\hline Motility & - & - & - & - \\
\hline Catalase & - & - & - & - \\
\hline Oxidase & + & + & + & + \\
\hline Citrate & + & - & - & + \\
\hline VogesProskauer & - & + & + & - \\
\hline Methyl Red & + & + & + & + \\
\hline Indole & - & - & - & - \\
\hline Urease & - & - & - & - \\
\hline Starch hydrolysis & - & - & - & - \\
\hline Tentative identity & $\begin{array}{l}\text { Lactobacillus } \\
\text { Plantarum }\end{array}$ & $\begin{array}{l}\text { Lactobacillus } \\
\text { Casei }\end{array}$ & Lactobacillus fermentum & $\begin{array}{l}\text { Lactobacillus } \\
\text { Plantarum }\end{array}$ \\
\hline
\end{tabular}

KEY:+ = Positive, - = Negative

Table 2. The proximate analysis of mango, banana and orange peels

\begin{tabular}{|c|c|c|c|c|}
\hline S/No & $\begin{array}{l}\text { Parameters } \\
\text { Investigated }\end{array}$ & Mango (\%) & Banana $(\%)$ & Orange (\%) \\
\hline 1 & Moisture Content & 10.28 & 9.80 & 10.36 \\
\hline 2 & Total Ash & 4.68 & 8.52 & 5.14 \\
\hline 3 & Total Fat & 4.92 & 6.29 & 6.84 \\
\hline 4 & Crude Fibre & 12.46 & 10.42 & 12.18 \\
\hline 5 & Crude Protein & 5.18 & 9.63 & 8.42 \\
\hline 6 & Carbohydrate content & 62.48 & 55.34 & 57.06 \\
\hline 6 & Sugar mg/100g & 6.24 & 6.82 & 6.56 \\
\hline 7 & TTA mg/100g & 0.31 & 0.28 & 0.26 \\
\hline 8 & $\mathrm{pH}$ & 4.30 & 6.00 & 4.70 \\
\hline
\end{tabular}

Key: $\%=$ Percentage, TTA = Titratable acidity.

The effect of $\mathrm{pH}$ variations on the production of lactic acid are shown in Figures $\mathrm{G}$ and $\mathrm{H}$ respectively and $\mathrm{pH}$ optimization experiments on L. plantarum showed that $\mathrm{pH} 5.0$ and 6.0 were best. 
Banana produced its highest yield $(5.40 \%)$ at $\mathrm{pH} 5.0$ while $\mathrm{pH} 6.5$ produced the lowest yield $(2.25 \%)$. Orange peels produced its highest yield $(4.05 \%)$ at $\mathrm{pH} 5.0 \mathrm{p}$ and lowest $(1.80 \%)$. at $\mathrm{pH}$ 6.5. When Lactobacillus casei was used, mango peels also produced the highest lactic acid of $(7.9 \%)$ at $\mathrm{pH} 6.0$, as did banana peels $(7.40 \%)$ and orange peels $(5.00 \%)$. The lowest yields were observed at $\mathrm{pH} 5.0$ as $4.50 \%, 3.60 \%$ and $1.35 \%$ for mango, banana and orange peels respectively.

The effects of inoculum size variation on the yield of lactic acid are shown in Figure A and Figure B. During the inoculum size optimization test for $L$. plantarum using mango, banana and orange peels, inoculum size of $2 \mathrm{ml}$ produced the highest yield of lactic acid.The production was $23.85 \%, 26.7 \%$ and $18.9 \%$ for mango, banana and orange peels respectively, while Lactobacillus caseihad the unusual high production of lactic acid at inoculum size of $1.0 \mathrm{ml}$ which was $17.10 \%$ for mango peels, $8.10 \%$ for banana peels and $6.30 \%$ for orange peels.

The impact of substrate variation for $L$. caseiand $L$. plantarumare shown in Figure $\mathrm{C}$ and Figure D respectively. Lactobacillus caseiand Lactobacillus plantarumproduced the highest amount of lactic acid with $4 \mathrm{~g}$ of substrate. The ranges of lactic acid produced by $L$. caseifor the three substrates were $5.90-13.50 \%$ for mango peels, $5.20-9.90 \%$ for banana peels and 3.80-9.00\% for orange peels, while $L$.

lantarum produced $4.10-9.00 \%$ for mango peels, $2.50-6.30 \%$ for banana peels and $1.80-5.40 \%$ for orange peels.
The optimized process for the production of lactic acid resulted from variation of the above named parameters. These were combined in a single fermentation for each of the organisms and different substrates to get optimum yields. The optimized conditions (Table 5) for L. plantarum were $\mathrm{pH} 5.0$, $4 \mathrm{~g}$ substrate, $2 \mathrm{ml}$ inoculum, $10 \mathrm{~g}$ of nitrogen source for 8 days resulting in $20.70 \%, 12.97 \%$ and $10.83 \%$ yield for mango, banana and orange peels respectively. For L. casei(Table 6), they were $\mathrm{pH}$ 6.0, $4 \mathrm{~g}$ of substrate, $1 \mathrm{ml}$ inocula size, $10 \mathrm{~g}$ of nitrogen source for 8 days resulting in $23.28 \%, 18.30 \%$ and $12.90 \%$ yield for mango, banana and orange peels respectively.

L. plantarum was inoculated in various wastes and incubated at uniform $\mathrm{pH}$ (6.0). Among the substrate, lactic acid production was found to be highest in mango peels $(5.94 \%)$, followed by banana peels $(3.60 \%)$ and orange peels $(3.40 \%)$.

Table 3. Percentage Production of Lactic acid by fermentation from mango, banana and orange peels using Lactobacillus plantarum

\begin{tabular}{|c|c|c|c|}
\hline \multirow[t]{2}{*}{ Fermentation time (Days) } & \multicolumn{3}{|c|}{ Lactic acid production (\%) } \\
\hline & $\begin{array}{l}\text { Mango peels } \\
\text { peels }\end{array}$ & Banana peels & Orange \\
\hline 1 & $1.650 \pm 0.150^{\mathrm{a}}$ & $1.050 \pm 0.150^{\mathrm{a}}$ & $1.200 \pm 0.150^{\mathrm{a}}$ \\
\hline 2 & $2.400 \pm 0.150^{\mathrm{a}}$ & $1.500 \pm 0.150^{\mathrm{b}}$ & $1.650 \pm 0.150^{\mathrm{a}}$ \\
\hline 3 & $3.150 \pm 0.260^{\mathrm{b}}$ & $2.100 \pm 0.150^{\mathrm{a}}$ & $2.250 \pm 0.260^{\mathrm{b}}$ \\
\hline 4 & $4.200 \pm 0.300^{\mathrm{c}}$ & $2.550 \pm 0.150^{\mathrm{a}}$ & $3.000 \pm 0.300^{\mathrm{c}}$ \\
\hline 5 & $5.70 \pm 0.912^{\mathrm{ab}}$ & $3.600 \pm 0.000^{\mathrm{a}}$ & $3.900 \pm 0.150^{\mathrm{a}}$ \\
\hline 6 & $10.53 \pm 1.114^{\mathrm{d}}$ & $5.400 \pm 0.687^{\mathrm{b}}$ & $6.750 \pm 0.450^{\mathrm{d}}$ \\
\hline 7 & $7.650 \pm 0.260^{\mathrm{b}}$ & $4.200 \pm 0.397^{\mathrm{c}}$ & $5.850 \pm 0.260^{\mathrm{b}}$ \\
\hline 8 & $6.300 \pm 0.520^{\mathrm{d}}$ & $3.300 \pm 0.150^{\mathrm{a}}$ & $4.200 \pm 0.397^{\mathrm{c}}$ \\
\hline
\end{tabular}

Key: Each value is a mean of three determinations \pm standard error of mean. Different superscripts across the columns are significantly different $(\mathrm{p}<0.05)$. 
Table 4. Percentage Production of Lactic acid by fermentation from mango, banana and orange peels using Lactobacillus casei

\begin{tabular}{|c|c|c|c|}
\hline \multirow[t]{2}{*}{ Fermentation time (Days) } & \multicolumn{3}{|c|}{ Lactic acid production (\%) } \\
\hline & Mango peels & Banana peels & Orange peels \\
\hline 1 & $2.100 \pm 0.150^{\mathrm{a}}$ & $1.500 \pm 0.150^{\mathrm{a}}$ & $1.050 \pm 0.150^{\mathrm{a}}$ \\
\hline 2 & $2.850 \pm 0.397^{\mathrm{c}}$ & $1.950 \pm 0.150^{\mathrm{a}}$ & $2.025 \pm 0.225^{\mathrm{b}}$ \\
\hline 3 & $3.450 \pm 0.397^{\mathrm{c}}$ & $2.700 \pm 0.520^{\mathrm{d}}$ & $2.400 \pm 0.150^{\mathrm{a}}$ \\
\hline 4 & $4.650 \pm 0.300^{c}$ & $3.450 \pm 0.397^{c}$ & $3.300 \pm 0.397^{\mathrm{c}}$ \\
\hline 5 & $6.150 \pm 0.150^{\mathrm{a}}$ & $4.200 \pm 0.397^{c}$ & $3.900 \pm 0.300^{\mathrm{c}}$ \\
\hline 6 & $12.03 \pm 1.091^{\mathrm{d}}$ & $8.10 \pm 0.520^{\mathrm{ab}}$ & $7.200 \pm 0.520^{\mathrm{ab}}$ \\
\hline 7 & $8.10 \pm 0.520^{\mathrm{ab}}$ & $5.700 \pm 0.300^{c}$ & $4.800 \pm 0.300^{\mathrm{c}}$ \\
\hline 8 & $6.600 \pm 0.300^{\mathrm{c}}$ & $4.667 \pm 0.167^{\mathrm{b}}$ & $4.067 \pm 0.467^{\mathrm{ab}}$ \\
\hline
\end{tabular}

Key: Each value is a mean of three determinations \pm standard error of mean. Different superscripts across the columnsare significantly different $(\mathrm{p}<0.05)$.

Nitrogen concentration was varied with yeast extract $(2.5 \mathrm{~g} / \mathrm{l}, 5 \mathrm{~g} / \mathrm{l}, 7.5 \mathrm{~g} / \mathrm{l}$ and $10 \mathrm{~g} / \mathrm{l})$ used for the two organisms (Figures $\mathrm{E}$ and $\mathrm{F}$ ). The results of these experiments showed that yield increased with increase in concentration of nitrogen. This implied that addition of nitrogen to fermentation media, at least at the concentrations tested influenced the production of lactic acid from agro-wastes.

All values giving the highest yields were put together in a flask to obtain an optimized yield (Tables 5 and 6). A yield of $22.50 \%$ was obtained on Day 6 at a $\mathrm{pH}$ of 5.0 , substrate amount of $4 \mathrm{~g} / 50$ $\mathrm{ml}$, nitrogen concentration of $10 \mathrm{~g} / \mathrm{l}$ and inoculum size of $2 \mathrm{ml}$ with L. plantarum, while with L. casei, a yield of $27.10 \%$ was obtained on Day 6 at a $\mathrm{pH}$ of 6.0 , substrate amount of $4 \mathrm{~g} / 50 \mathrm{ml}$, nitrogen source of $10 \mathrm{~g} / \mathrm{l}$ and an inoculum size of $1.0 \mathrm{ml}$.

Table 5. Optimization Production of Lactic acid from mango, banana and orange peels using Lactobacillus plantarum

\begin{tabular}{|c|c|c|c|}
\hline \multirow{2}{*}{ Fermentation time (Days) } & \multicolumn{3}{|c|}{ Lactic acid production (\%) } \\
\hline & Mango peels & Banana peels & Orange peels \\
\hline 1 & $4.200 \pm 0.397^{\mathrm{c}}$ & $3.750 \pm 0.150^{\mathrm{a}}$ & $3.000 \pm 0.300^{\mathrm{b}}$ \\
\hline 2 & $5.100 \pm 0.397^{\mathrm{c}}$ & $4.667 \pm 0.309^{\mathrm{b}}$ & $3.900 \pm 0.150^{\mathrm{a}}$ \\
\hline 3 & $6.600 \pm 0.300^{\mathrm{b}}$ & $5.700 \pm 0.150^{\mathrm{a}}$ & $4.967 \pm 0.017^{\mathrm{a}}$ \\
\hline 4 & $8.700 \pm 0.600^{c}$ & $6.600 \pm 0.300^{\mathrm{b}}$ & $6.000 \pm 0.150^{\mathrm{a}}$ \\
\hline 5 & $12.96 \pm 0.267^{\mathrm{b}}$ & $8.400 \pm 0.300^{\mathrm{b}}$ & $6.900 \pm 0.300^{b}$ \\
\hline 6 & $20.700 \pm 1.039^{\mathrm{d}}$ & $12.97 \pm 0.267^{\mathrm{ab}}$ & $10.83 \pm 0.934^{\mathrm{cd}}$ \\
\hline 7 & $16.50 \pm 2.163^{\mathrm{cd}}$ & $10.833 \pm 0.933^{\mathrm{cd}}$ & $7.500 \pm 0.300^{b}$ \\
\hline 8 & $12.03 \pm 1.091^{\mathrm{cd}}$ & $8.400 \pm 0.300^{\mathrm{b}}$ & $6.600 \pm 0.300^{\mathrm{b}}$ \\
\hline
\end{tabular}

$\underline{\text { Key: Each value is a mean of three determinations } \pm \text { standard error of mean. Different superscripts across the columnsare significantly different }}$ $(\mathrm{p}<0.05)$. 
Table 6. Optimization Production of Lactic acid from mango, banana and orange peels using Lactobacillus casei

\begin{tabular}{|c|c|c|c|}
\hline \multirow[t]{2}{*}{ Fermentation time (Days) } & \multicolumn{3}{|c|}{ Percentage Lactic acid production (\%) } \\
\hline & Mango peels & Banana peels & Orange peels \\
\hline 1 & $4.667 \pm 0.309^{c}$ & $3.750 \pm 0.150^{\mathrm{a}}$ & $4.200 \pm 0.397^{\mathrm{c}}$ \\
\hline 2 & $5.717 \pm 0.381^{\mathrm{c}}$ & $4.350 \pm 0.300^{\mathrm{b}}$ & $4.667 \pm 0.309^{c}$ \\
\hline 3 & $6.450 \pm 0.397^{\mathrm{c}}$ & $4.983 \pm 0.017^{\mathrm{a}}$ & $5.267 \pm 0.292^{\mathrm{ab}}$ \\
\hline 4 & $9.93 \pm 1.588^{\mathrm{cd}}$ & $5.867 \pm 0.433^{\mathrm{d}}$ & $7.20 \pm 0.520^{\mathrm{d}}$ \\
\hline 5 & $18.48 \pm 3.225^{\mathrm{cd}}$ & $10.23 \pm 1.338^{\mathrm{d}}$ & $12.90 \pm 1.587^{\mathrm{ab}}$ \\
\hline 6 & $23.28 \pm 2.384^{\mathrm{cd}}$ & $12.90 \pm 1.587^{\mathrm{ab}}$ & $18.30 \pm 1.587^{\mathrm{ab}}$ \\
\hline 7 & $14.77 \pm 2.067^{\mathrm{cd}}$ & $9.000 \pm 0.520^{c}$ & $12.03 \pm 1.091^{\mathrm{ab}}$ \\
\hline 8 & $8.700 \pm 0.794^{c}$ & $6.600 \pm 0.300^{c}$ & $7.200 \pm 0.520^{\mathrm{d}}$ \\
\hline
\end{tabular}

Kev: Each value is a mean of three determinations \pm standard error of mean. Different superscripts across the columns are significantly different $(\mathrm{p}<0.05)$.

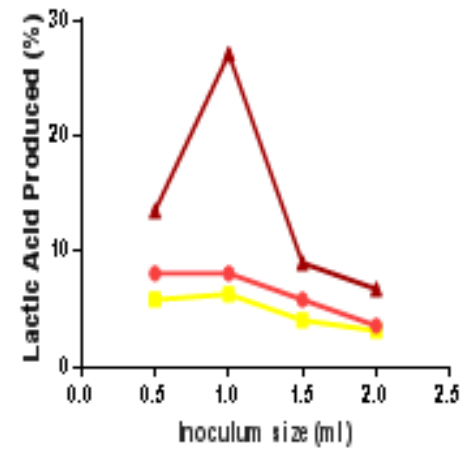

Figure A: Percentage of lacticacid produced against inoculum size of Lactobacillus casei

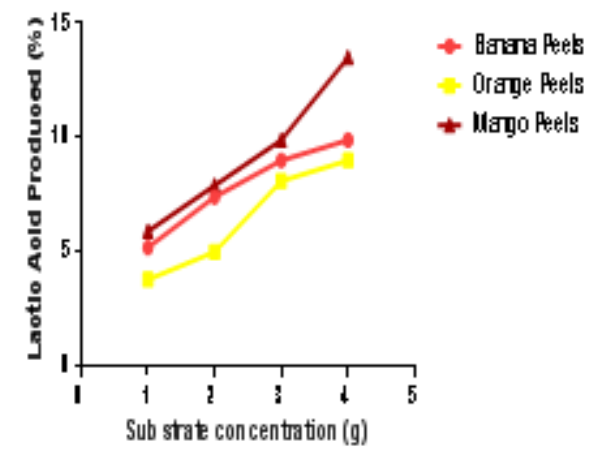

Figure C: Percentage of lactic acid produced with substrate using Lactobacillus casei

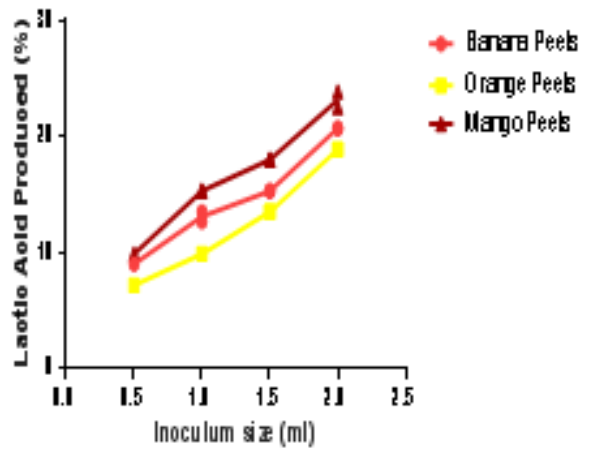

Figure B: Percentage oflactic acid produced against inoculum size of Lactobacillus planim rum

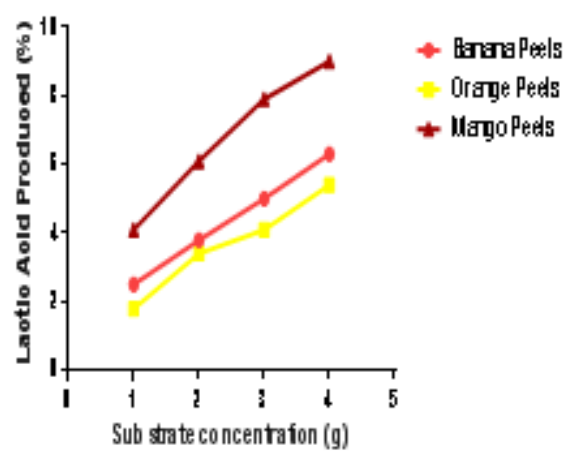

Figure D: Percentage of lactic acid produced with substrate using Lactobacillus planimum 


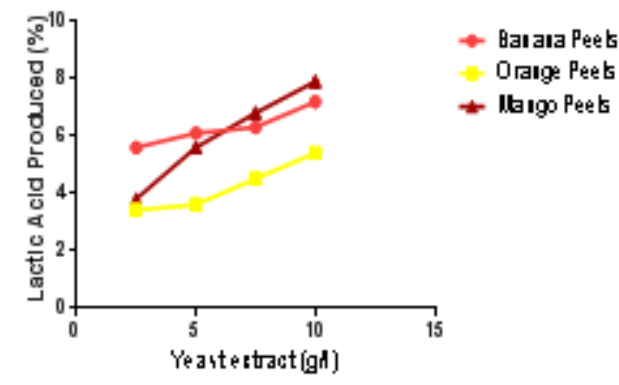

Figure E: The effect of yeast extract as a nitrogen source on the percentage of lactic acid produced by Lactobacillus casai

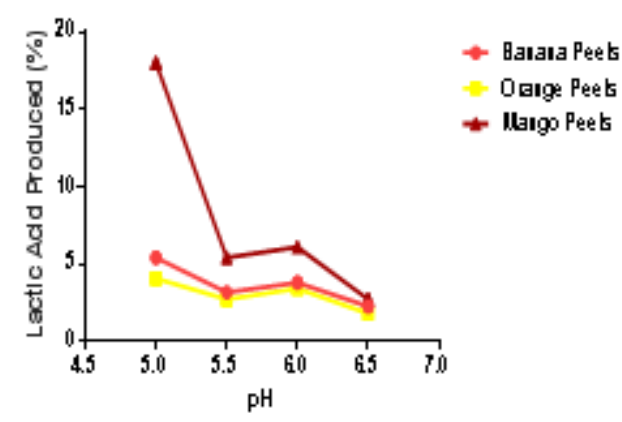

Figure G: $\mathrm{pH}$ optimization and percentage of lactic acid produced by Lactobacillus plantarum

With both organisms, the $10 \mathrm{~g}$ yeast extract gave the highest yield for lactic acid production. L. casei gave $7.90 \%, 7.20 \%$ and $5.40 \%$ for mango, banana and orange peels respectively (Figure E), while $L$. plantarum gave the highest yield of $6.80 \%, 6.30 \%$ and $4.50 \%$ on day 6 for mango, banana and orange peels respectively (Figure F).

\section{Discussion}

\section{Isolation and Identification of test organisms}

The use of autochthonous lactic acid bacteria (LAB) for the production of cheese and organic acid was reported by Renes et al., (2019). This is in agreement with the indigenous bacteria used in this work. In a report by Yang et al., (2016), eighty-two strains of LAB were isolated from fruit residues such as banana leaf, pineapple peel and papaya peel. In another study on lactic acid production, the organisms were isolated from spent coffee mucilage (Bretón-Toralet al., 2017). In a study by Palsaniyaet al. (2012) on production of bacterial alkaline protease, the bacteria used were isolated from the soil. The $\mathrm{pH}$ range used in this work was 5 to 6.5 with highest yield obtained at $\mathrm{pH} 5$ and 6 respectively for $L$. plantarum and $L$. casei. This is not in concord with the report of Couriet al. (2000) who reported a $\mathrm{pH}$ of 3 for orange peels and a $\mathrm{pH}$ of 3.9 for mango. Wilkins et al. (2007) reported a $\mathrm{pH}$ range of $4.3-4.4$ for lactic acid production

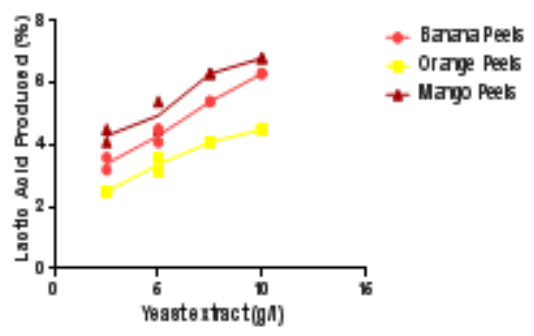

Figure F: The effect of yeast extract as a nitrogen source on the percentage of lactic acid produced by Lactobacillus plantanum

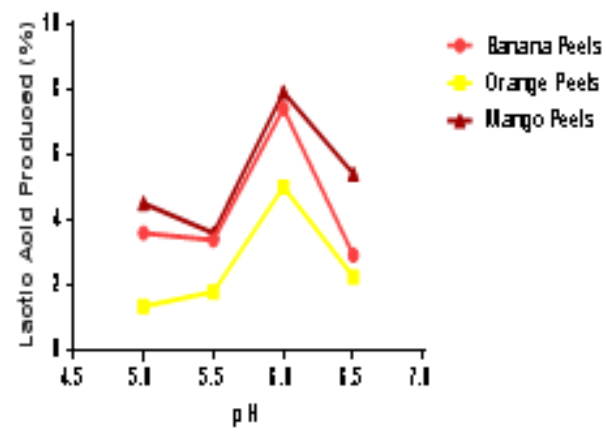

Figure $\mathrm{H}$ : $\mathrm{pH}$ optimization and percentage of lactic acid produced by Lactobacillus casei

from banana peels. Tang et al. (2017) reported that the highest lactic acid was generated at $\mathrm{pH} 5$ using fresh food waste as the inoculum. Tang et al. (2016) also reported the highest production of lactic acid at pH 6. In the work of Wu et al. (2015), lactic acid was produced at $\mathrm{pH} 4.0$ with improvement at $\mathrm{pH} 5.0$.

The inocula applied by Tang et al. (2017) were methanogenic sludge, fresh food waste and anaerobic activated sludge. These inocula varied from that used in this study showing that there are no limitations to inocula source. Lactic acid production increased progressively with increase of inoculum size for L. plantarum with the highest production observed when $2 \mathrm{ml}$ of the prepared inoculum was used for all the substrates with yields of $23.85 \%, 26.7 \%$ and $18.9 \%$ for mango, banana and orange peels respectively. However, the reversed production was observed when $L$. casei was used; $1.0 \mathrm{ml}$ of the prepared inoculum gave the highest production of lactic acid with $17.10 \%$, $8.10 \%$ and $6.30 \%$ for mango, banana and orange peel, while $0.5,1.5 \mathrm{ml}$ and $2.0 \mathrm{ml}$ produced lower amount of lactic acid (Figures C and D). It was important to monitor the optimum inoculum size for the production of lactic acid because low inoculum might be insufficient to utilize the available substrate and that might lead to reduction in the quantity of lactic acid produced while 
excessive inoculum sizes might form superfluous biomass and cause a significant exhaustion of the nutrients that should otherwise have been utilized for the production of lactic acid (Shin et al., 2010; Pradeep et al., 2014).

The quantity of lactic acid produced increased progressively from day 1 to 6 and then dropped sharply (Table 3). This might be due to the depletion of nutrient and accumulation of toxic metabolites which resulted in reduced production of lactic acid on day seven (Quiroga et al., 2014). The growth pattern observed with L. casei (Table 4) which gave the higher yields agreed with the work of John et al. (2007) and Rutuja et al. (2016) on lactic acid production by Lactobacillus sp. using vegetable waste who also reported highest production by day 5 and day 6 .

Increase in nitrogen concentration caused an increase in lactic acid production. This agrees with the findings of Chinedu et al. (2011) where the concentration of nitrogen was varied for improved production of cellulase by Aspergillus niger, Penicilliumchrysogenumand

Trichodermaharzianum. Arakaki et al. (2001) also found improved biomass production in yeasts grown under submerged fermentation when nitrogen concentration was increased. The effectiveness of nitrogen in this study might be because nitrogen was one of the major elements required for nucleic acid synthesis in microorganisms during the biosynthesis of lactic acid. The study of Wee et al. (2006) also lends further credence to this observation. After the optimization process, L. casei showed a higher lactic acid producing ability than $L$. plantarum.

\section{Conclusions}

Mango peels produced the largest amount of lactic acid, while orange peels were found to produce the lowest amount. Further studies are required on mango peels in order to improve its use in production of lactic acid.

\section{Acknowledgement}

The authors acknowledge the Department of Microbiology, University of Ilorin for providing enabling environment for this research

\section{References}

AOAC (2000) Official methods of analysis, Association of Official Analytical ChemistsWashington DC, U.S.A.

Arakaki, A.H., Vandenberghe, L.P., Soccol, V.T., Masaki, R., Filho, E.F., Gregório, A., Soccol,C.R. (2001) Optimization of biomass production with copper bioaccumulation by yeasts insubmerged fermentation. Brazilian Archives of
Biology and Technology 54(5): $1027-$ 1034.

Benninga, H. (1990) A History of Lactic Acid Making. A Chapter in the History of Biotechnology. Dordrecht, London.

Bernstad, A., Malmquist, L., Truedsson, C., Jansen, J.C. (2013) Need for improvements inphysical pretreatment of sourceseparated household food waste. Waste Management33(3): 746-754.

Bogaert, J.C., Coscach, P. (2000) Poly (lactic acids): A potential solution to plastic wastedilemma.

Macromolecule Symposium 153: 287-303.

Bretón-Toral, A, Trejo-Estrada, S., Mcdonald, A.G. (2017). Lactic Acid Production from Potato

Peel waste, spent coffee grounds and almond shells with undefined mixed cultures isolated from coffee mucilage from Coatepec Mexico. Fermentation Technology 6(1): 1-6.

Chinedu, S.N., Okochi, V.I., Omidiji, O. (2011) Cellulase production by wild-type Aspergillus

niger,

PenicilliumchrysogenumandTrichodermah arzianumusing waste cellulosic materials. Ife Journal of Science 13(1): 57-62.

Couri, S., Terzi, S.C., Pinto, S.G., Freita, S.P., Costa, A. C. (2000) Hydrolytic enzymeproduction in solid state fermentation by Aspergillus niger3T5B8. Process Biochemistry 36: 255-261.

Cullison, A.E. (1982) Feeds and Feeding. $3^{\text {rd }}$ ed. Reston Publishing Company Inc., Reston, Virginia, $628 \mathrm{pp}$.

Dai, X., Duan, N., Dong, B., Dai, L. (2013) Highsolids anaerobic co-digestion of sewage sludge and food waste comparison with monodigestions: stability and performance. WasteManagement 33: 308316.

Gonzalez, C.J., Encinas, J.P., Gracia, L.M.L., Otero, A. (2000) Characterization and identification of lactic acid bacteria from freshwater fishes. Journal of Food Microbiology 17: 383-391.

Gunders, D. (2012) Wasted: How America is losing up to 40 percent of its food from farm tofork to landfill. Natural Resources Defense Council. Issues in food and agriculture.

http://www.nrdc.org/food/files/wasted-food-IP.pdf.

Hofvendahl, K., Hahn-Hägerdal, B. (2000) Factors affecting the fermentative lactic acid production from renewable resources. Enzyme and Microbial Technology 26(2): 87-107. 
Holt, J.G. (1994) Bergey's manual of determinative bacteriology. William and Wilkens, London.

John, R.P., Nampoothiri, K.M., Pandey, A. (2007) Fermentative production of lactic acid from

biomass: An overview onprocess developments and uture perspectives. Applied Microbiology and Biotechnology 74(3): 524-534.

Ibitoye, A.A. (2005) Laboratory manual on basic method of plant analysis. Practical Manual on Plant Analysis. pp: 2-5.

Jörissen, J., Priefer, C., Bräutigam, K.R. (2015) Food waste generation at household level:results of a survey among employees of two European research centers in Italy and Germany. Sustainability 7: 26952715.

Khalaf, S.A. (2001) Lactic acid production by inter specific hybrids of specific strain Rhizopus strain from potato processing peel waste. Egyptian Journal of Microbiology 36: 89102.

Mahantesh, M.P., Ajay, P., Tamatam, A., Ramana, K.V. (2010) Isolation and characterization of lactic acid bacteria from curd and cucumber.Indian Journal of Biotechnology 9(2): 166-172.

Mridul, U., Preethi, K. (2014) Fermentative utilization of fruit peels waste for lactic acid production by Lactobacillus plantarum. Indian Journal of Applied Research 4(9).

Nandini, S, Nandini, K.E., Sundari, S.K. (2014) Food and agriculture residues (FAR): A

potential substrate for tannase and garlic acid production using competent microbes. Journal of Bioprocessing and Biotechniques5: 193.

Omojasola, P.F., Adetitun, D.O., Oshin, O.O., Omojasola, T.P. (2009) Environmental Health Hazard Assessment of Hospital Wastes in Ilorin Metropolis. Nigerian Journal of Microbiology.23(1): 18781885.

Palsaniya, P., Mishra, R., Beejawat, N., Sethi, S., Gupta, B.L. (2012) Optimization of alkaline protease production from bacteria isolated from soil. Journal of Microbiology and Biotechnology Research 2(6): 858-865.

Pavezzi, F.C., Gomes, E., Da Silva, R. (2008) Production and characterization of glucoamylasefrom fungus Aspergillusawamori expressed in yeast Saccharomyces cerevisiae using different carbon sources. Brazilian Journal of Microbiology 39(1): 108-114.
Pradeep, P., Vijaya, S.R.O., Sang, E.O., Chulkyoon, M.(2014) Biotechnological potentialities and valorization of mango peel waste: A Review. SainsMalaysiana43(12): 19011906.

Purkayastha, R.D. (2012) Forming community enterprises using vermicomposting as a tool for socio-economic betterment. International Proceedings of Economics Development and Research 29: 83-87.

Quiroga, G., Castrillon, L., Fernandez-Nava, Y., Maranon, E., Negral, L., RodriguezIglesias, J.,

Ormaechea P.(2014) Effect of ultrasound pretreatment in the ananerobic co-digestion of cattle manure with food waste and sludge. Bioresource Technology 154: 74-79.

Ray, R.C., Swain, M.R. (2011) Cassava: Farming, Uses and Economic Impacts Nova, Hauppauge, New York. pp 1-32.

Renes, E., Ladero, V., Tornadijo, M. E., Fresno, J.M. (2019) Production of sheep milk cheese with high $\gamma$-aminobutyric acid and ornithine concentration and with reduced biogenic amines level using autochthonous lactic acid bacteria strains. Food Microbiology 78: 1-10.

Rounsefell, B.D., O'sullivan, C.A., Chinivasagam, N., Batstone D., Clarke, W.P. (2013) Fate of pathogen indicators in a domestic blend of food waste and wastewater through a two-stage anaerobic digestion system. Water Science and Technology67: 366373.

Rutuja, D., Rohinee, P., Anita C. (2016) Lactic acid production by Lactobacillus sp. using vegetable waste. International Journal of Research in Pure and Applied Microbiology pp. 227-384.

Shin, S.G., Han, G., Lim, J., Lee, C., Hwang, S. (2010) A comprehensive microbial insight into two-stage anaerobic digestion of food waste-recycling wastewater. Water Resources 44: 4838-4849.

Tang, J., Wang, X.C., Hu, Y., Zhang, Y., Li, Y. (2017) Effect of $\mathrm{pH}$ on lactic acid production fromacidogenic fermentation of food waste with different types of inocula. BioresourceTechnology224: 544-552.

Tang, J., Wang, X., Hu, Y., Zhang, Y., Li, Y. (2016) Lactic acid fermentation from food waste with indigenous microbiota: Effects of $\mathrm{pH}$, temperature and high OLR. Waste Management52: 278-285.

Vickroy, T.B. (1985) Lactic acid In: M. MooYoung, ed. Comprehensive biotechnology: The principles, applications and regulations of biotechnology in industry, 
agriculture and medicine.Pergamon Press, New York, 3: 761- 776.

Wee, Y., Kim, J., Ryu, H. (2006) Biotechnological production of lactic acid and its recentapplications. Food Technology and Biotechnology 44(2): 163-172.

Wilkins, M.R., Widmer, W.W., Grohmann, K. (2007). Simultaneous saccharification and fermentation of citrus peel waste by Saccharomyces cerevisiae to produce ethanol. Process Biochemistry42: 16141619.

Wu, Y., Ma, H., Zheng, M., Wang, K.(2015) Lactic acid production from acidogenic fermentation of fruit and vegetable wastes. Bioresource Technology191: 53-58.

Yang, J., Tan, H., Cai, Y. (2016) Characteristics of lactic acid bacteria isolates and their effect on silage fermentation of fruit residues. Journal of Dairy Science 99(7): 53255334. 